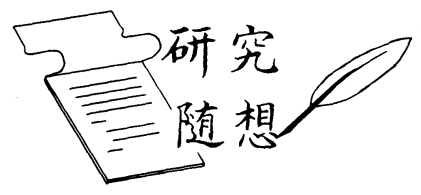

\title{
研究と学会活動の思い出*
}

日本機械学会論文集 $(C$ 編)

73 巻 730 号 (2007-6)

鈴木浩平*1

\section{My Memories of Research Experience and Academic Activity}

\author{
Kohei SUZUKI*2 \\ *2 Open University, Tokyo Metropolitan University, \\ 1-1 Minamiosawa, Hachioji-shi, Tokyo, 192-0397 Japan
}

Key Words : Vibration, Seismic Engineering, Modeling, Damping, Structural Dynamics

\section{1. はじめに}

2006 年 3 月に定年退職し, 研究の前線からは退いた 形になった。多くの先輩, 諸先生, 同僚および研究室 の学生諸君に支えられた充実した 40 年間であった. 研究や学会活動の経緯の中で心に残る思い出をいくつ か綴ってみたい.

\section{2. 東大生研時代}

1966 年 3 月に北大の機械工学科を卒業し, 4 月から 東大の生産技術研究所に助手として採用され研究生活 のスタートを切った。当時, 東大生研は港区六本木竜 土町と呼ばれた地区にあったが, 第 2 部(機械・船 舶・精密系の部局) の佐藤壽芳研究室の中でその後約 8 年間の研究生活を過ごした. 後に通産省・機械技術 研究所長になられた佐藤先生は新進気鋭の若手助教授 であり，研究者としての心構えが不十分であった私を 真摰かつ熱心に指導して下さった。先生は, 本学会会 長, 東大工学部長, 冨山県立大学学長などを歴任され た藤井澄二先生の研究室の出身であり, 機械構造物の 耐震設計に関する研究で博士号を取得されていた。現 在では, 機械系の耐震, 免震, 制震などの領域で学位 を取得した人は多数に上るが, 佐藤先生はその第一号 でありこの分野の先駆者の一人である.

佐藤先生は生研に着任されてからは, 工作機械の動

* 原稿受付 2007 年 4 月 5 日.

*1 正員, フェロー, 首都大学東京, オープンユニバーシティ (㤩192-0397 八王子市南大沢 1-1).

[著者略歴] 1942 年 6 月 25 日生まれ. 主として機械系構造物, 配管系などの耐震, 制振技術に関する研究に従事. 2006 年 3 月 まで東京都立大学および首都大学東京教授. 現在, 同大学名誉 教授, 副オープンユニバーシティ長.

E-mail : k-suzuki@ecomp.metro-u.ac.jp
力学, 計測工学の分野に研究の主体を移されつつあつ たが，私には耐震分野の方向に進むことを示唆され た. 結局, この助言により, 常に耐震工学を念頭にお きながら，その後の研究を進めることができたことに なり，そのご見識に感謝している．生研では研究室外 でも実に多彩な経験をさせていただいた．特に専門分 野を共有する柴田碧研究室の方々とは深い親交を得る ことができた。柴田先生はすでに原子力発電所の圧力 容器や配管系, 化学プラントなどの耐震研究のリーダ ーとして研究プロジェクトを進めておられ，私もその 一員に加えて下さった。

柴田研究室は耐震以外の分野, 例えば, 流体振動, 鉄道車両の動力学, 自動設計法などの研究にも意欲的 に取り組まれており,きら星のごとく俊秀が集まって いた. 原文雄, 宮本昌幸, 清水信行, 出澤正徳, 藤田隆 史, 曾我部潔, 福田敏男などの諸氏であり, その後各 分野のリーダーとして活躍される人たちばかりで, 大 変活発な研究室であった。柴田研究室や本郷の藤井研 究室のゼミやイベントに参加して, 私は強い刺激を受 けることができた。

生研の外でも研究仲間を得ることができた，RAPRAS 研究会 (Random Process Analysis をもじって 命名)というグループを作り, 座古勝, 北川良和, 渡辺 嘉二郎, 伊藤哲次, 千葉利晃, 利光聡の 6 氏に, 当時柴 田研究室の学生であった清水, 曾我部両氏と私を含め た 9 名で定期的に集まり，さまざまなテーマについて 討論したり共同研究したりした. 1985 年には座古氏 を幹事として, これらの成果をまとめ「機械・構造物 の振動一一その対策と解析—— (養賢堂)として出版 した. 


\section{3. 都立大時代}

1974 年に東京都立大学の機械工学科に任用され, 大 学教員としての新しい道を歩むことになった. 生研で 自由気ままな研究生活をしていた私にとり, 多数の学 生を相手にする講義や難解な “大学運営用語”を交え た教員会議での討論などには戸惑いを感じることが多 く,やや研究意欲を削がれた時期があった. 当時の大 学や学部, 学科には大学紛争後の不安定な状況がまだ 残っており, 発生した問題処理のための時間の浪費に 苦痛を感じていた。

しかし，このような状況の中でも平山直道, 加藤宏 先生らの先輩, 同年代の西村尚, 古川勇二, 渡辺敬三 氏らからの激励や助言で基本的には研究生活を維持す ることができ，同僚の有難さを強く感じた，研究室内 での助手や学生諸君との共同作業を順調に進めること ができ, 徐々にではあるが成果を発表できたのは幸い だった。研究室で学んだ青木繁, 曽根彰, 松本金矢, 河之辺浩, 長松昌男, 渡邊鉄也, 砂子田勝昭, 西田英 一，成澤哲也，今村仁，鄭萬溶，馬平，R. Reddy，細矢 直基らの諸氏らが続々とユニークな研究で学位を取得 し, 現在国内外の大学等で活躍している. 現在までに, 研究室から日本機械学会賞 (論文賞)を 2 件, 研究奨励 賞を 6 名の受賞を得ることができた。

退職後は, 研究室の後継者の吉村卓也氏が, 新しい 分野の開拓を進めており，研究の幅とレベルがさらに 発展することを願っている.

\section{4. 学会などの研究活動}

$4 \cdot 1$ 分科会活動など 日本機械学会では機械力 学分野(機械力学計測制御部門)で実に多くの先達や友 人との親交を得ながら研究活動をさせていただいた。 耐震工学の分野では 1980 年から約 6 年間, 下郷太郎 先生に主査をお願いして「機械構造物の耐震設計と構 造動力学に関する研究分科会」を設立し幹事として力 を注いだ。この企画は, 藤田勝久, 近藤尚夫, 清水信 行の諸氏らと相談して実現したものであったが，耐震 分野に限らずモード解析, 振動制御, 最適設計法など の専門家にも参画していただき有意義な成果が得られ たと感じた. 長松昭男, 背戸一登, 吉田和夫, 山川宏 の諸先生も積極的に加わって下さり，その成果を委託 出版「耐震設計と構造動力学」(日本工業出版)として まとめることができた，耐震に関する分科会は，一時 中断したが 1995 年の阪神淡路大震災の後に清水信行 氏を主査として設立され，現在では兽根彰氏を中心に 活動している.
耐震以外の課題としては, 1987 年に長松, 背戸先生 の助言と支援をいただき「モデリングに関する研究分 科会」を設立した。設計概念の構築から具体的な対象 物の動的設計作業に至るまでのモデル化についての問 題について研究交流を行い, 2 期 4 年にわたる成果を 「動設計とモデリング」(オーム社)として出版するこ とができた，大熊政明氏が幹事として企画・運営に尽 力された.

分科会活動として最も長期間力を注いだのは, 1989 年に設立した「ダンピング研究会」であった．当時, アメリカで宇宙航空分野で毎年開催されていた Damping Conference の影響も受けて, 機械工学に関 する振動低減 (ダンピング) 技術に関心をもつ研究仲間 が集まり，最初は非公式に進めていた勉強会を分科会 として発展させた。この会では当初から能動制振は対 象外とした．機械力学の分野ではすでに背戸一登, 吉 田和夫, 野波健蔵先生らが能動制振に関する広範な分 野を統合した研究活動を展開し, 国際会議(MOVIC) を主催されるまでになっていたので関連する課題は共 存できると考えたからであった. ダンピング研究会で は主として ( 1 ) 制振材料の開発と応用，（2)制振装置， (3) 構造物の制振技術の体系化と基準化をターゲット とした. 大学等からの関連研究者はもとより, 金属・ 非金属系の材料メ一力, 重工業, 建設業, 自動車関連, 装置開発など多彩な企業からの参加を得ることになっ た. 3 年前に浅見敏彦氏が主査を継承してくださり， 現在約 100 名以上のメンバーで活動している.

ダンピング技術に関しては, 研究協力部会 (現, 産学 官連携センター)の RC 研究分科会を 4 期 8 年間主宰 した. 大亦絢一郎, 井上嘉雄, 松久寛, 佐藤美洋の諸 先生らの強力な支援を得て多くの成果を得ることがで きた. 学会賞を得た松久先生らの「スウィングダンパ の開発」はその代表的な成果である，RC 分科会は現 在井上嘉雄氏を主査として新展開を企っている。

ダンピング技術に関しては，拙著「振動を制する」 (オーム社テクノライフ選書)，「振動のダンピング技 術」(清水信行監修, 養賢堂),「粘弾性ダンピング技 術ハンドブック」（鈴木・浅見・井上・佐藤・入江共 訳, 丸善)が出版された。

$4 \cdot 2 \mathrm{ASME}$, 日本地震工学会など 世界地震工 学会議 (WCEE) や国際原子炉構造力学会議 (SMiRT) などの大規模な国際会議にも何度も出席し, 研究発表 を行ってきたが, 最も熱心に参画した会議はASME が毎年開催する Pressure Vessels and Piping(PVP) Conference であった. ASME 主体で開催されるこの 会議は 30 ケ国以上が集う国際会議であり, JSMEは 
常に多数の参加者を送っている. 1985 年のシカゴで の会議に出席して以来, 結局現在まで毎年参加したこ とになる. 発表した研究内容は大学での独自研究もあ ったが, 多くは各企業との共同研究や原子力工学試験 センター(現, 原子力安全基盤機構)で実施された多度 津大型振動台等を用いての耐震性実証試験の成果に関 するものなどであった. PVP 会議を, JSMEとの共 催とすることに尽力し, 1988 年に原文雄氏を JSME 側の Chair として Hawaii での開催に成功したこと は忘れられない. JSME 側の強力な協力があっての 開催であり,この成功を受けてその後も数年ごとに JSME との共催で開催されている. ASMEのPVP 部門は, JSMEにはない横断的部門であり, 材料力学, 機械力学, 流体工学を含む広範な研究者, 技術者から 構成されている.JSMEにもこのような横型の部門 が設立されてよいと考えている.これらの活動が評価 されたのか, この度, ASMEが米国人以外の研究者に 贈る栄誉ある賞, Calvin W. Rice Lecture 賞を受賞し, 光栄に感じている.
国内では, 約 8 年前に地震工学に関する横断的学会 として日本地震工学会が設立された。建築, 土木, 地 盤, 地震学の分野とともに機械工学も構成分野となっ ている. 約 50 年前に藤井, 柴田, 佐藤先生らにより切 り拓かれた機械系の地震工学が体系として確立されて きたことの成果と考えている.このたび, 機械工学系 から初めて次期会長に選出されたのであと 2 年間, こ の分野での活性化に力を注ぎたいと思っている. 次世 代以降の若い方々が, 未解決の問題が山積している機 械系の地震工学を担って欲しいと念願している.

\section{5. 終わりに}

長いようでもあり，あっという間の 40 年だった気 もする. やり残したことの多さに呆然とするが, 一方 では多くの方々の扔陰で能力を超える仕事ができたよ うな満足感もある. 本稿に記すことができなかった 方々を含めてお世話になった皆様仁改めて感謝の意を 記したい. 